\title{
Determination of optimum wavelength and derivative order in spectrophotometry for quantitation of hydroquinone in creams
}

\author{
Pedro López García*, Maria Inês Rocha Miritello Santoro, Anil Kumar Singh, Erika Rosa Maria \\ Kedor-Hackmann
}

Departament of Pharmacy, Faculty of Pharmaceutical Sciences, University of São Paulo

*Correspondence:

P. L. García

Departament of Pharmacy

Faculty of Pharmaceutical Sciences

University of São Paulo

Caixa Postal 66083

05508-900 - São Paulo - SP, Brazil

E-mail: pedrolg@usp.br
UV derivative spectrophotometry was used for quantitative determination of hydroquinone in creams. The aim of this work was to investigate optimum wavelength and order of derivative, and to validate the proposed spectrophotometric method. The results of standard curves were calculated and statistically analyzed through the least squares method in the interval from 10.0 to $26.0 \mu \mathrm{g} / \mathrm{mL}$, in the first, second, third and fourth order derivatives. The quantitative determination was carried out by using the zerocrossing (Z-C) and zero-peak (Z-P) methods. The proposed method is simple, of low cost and provides reliable results in order to be used in quality control of creams containing hydroquinone as active substance.
Uniterms

- Hydroquinone

- UV derivative spectrophotometry

- Quality control

\section{INTRODUCTION}

The hyperpigmentary disorders of the skin are caused by the over production of melanin, either by a normal or increased number of melanocytes, or by hormonal disorders (Cecil, 1993; Silva, Rezende, 1998). The hydroquinone (HQ) has been used for decades in creams, gels and lotions for the treatment of these disorders. It is the most frequently used compound in skin-toning preparations (Palumbo et al., 1991; Katsambas, Antoniou, 1995; Mohamed, Mohamed, 1998). It belongs to the group of phenols and alike most compounds of this group, it easily undergoes oxidative degradation, principally in the presence of metallic ions, high concentration of oxygen, high $\mathrm{pH}$ and on exposure to light (Connors et al., 1986; Ullmann's, 1999). The effects of HQ are transitory and concentrations below $3.0 \%$ do not cause skin injuries, however concentration above $5.0 \%$ could provoke local irritation being this the main reason for the validation of a simple method (Bleehen, 1977; Hardman et al., 1996; Zanini and Oga, 1989).

Several analytical methods for the determination of HQ in skin-toning preparations are described, including high performance liquid chromatography (Firth, Rix, 1986; Gagliardi et al., 1987; Borremans et. al., 1999), capillary electrochromatography (Desiderio et al., 2000), micellar chromatography (Sakodinskaya et al., 1992) and other analytical techniques (Wang, 1995; Cruz, Fatibello-Filho, 2000; Rueda et al., 2003).

The HQ shows a broad band of absorption in the UV region between 190 and $350 \mathrm{~nm}$, whose spectrum can be represented by the curve $A=f(\lambda)$, where $A$ is absorbance and $\lambda$ the wavelength. From this curve, successive derivatives can be calculated at each point:

$$
\frac{\delta A}{\delta \lambda}, \frac{\delta^{2} A}{\delta \lambda^{2}}, \ldots \frac{\delta^{n} A}{\delta \lambda^{n}}
$$


With the obtained values, the differential curve can be traced $\frac{\delta^{n} A}{\delta \lambda^{n}}$ giving rise to derivative spectrum of order $n$. The derivative spectrophotometry is based on the use of these spectra (Hackmann et al., 1991; Hopkala, Kowalczuk, 2000; Karpiñska, 2004).

The aim of this work was to determine most appropriate wavelength, as well as order of the derivative for quantitative determination of HQ in creams preparation (García et al., 2005). Such selection contributes to the development and validation of simple and reliable method for the quality control of cream preparations containing this substance.

\section{MATERIAL AND METHODS}

\section{Chemicals}

Hydroquinone (99.8\%), kindly supplied by Laboratórios Stiefel S.A. (São Paulo, Brasil), sulfuric acid (analytical grade) Merck $^{\circledR}$ (São Paulo, Brasil). Distilled water was used to prepare all solutions.

\section{Samples}

The cream preparations were obtained from a local compounding pharmacy. Sample I: $2 \mathrm{~g} \mathrm{HQ} / 100$ g cream; Sample II $4 \mathrm{~g} \mathrm{HQ} / 100 \mathrm{~g}$ cream and Sample III $4 \mathrm{~g} \mathrm{HQ} / 100 \mathrm{~g}$ cream.

\section{Instrumentation and analytical conditions}

The methods were developed on a UV-Vis spectrophotometer UV-1601 (Shimadzu ${ }^{\circledR}$ ) using $1.0 \mathrm{~cm}$ quartz cell and data were processed with online UVPC v3.91 Personal Spectroscopy Software $\left(\right.$ Shimadzu $\left.^{\circledR}\right)$. The wavelength interval was established between 190 and 350 $\mathrm{nm}$, the delta lambda was $2 \mathrm{~nm}$, the average screening speed was $370 \mathrm{~nm} / \mathrm{min}$ and the amplitude axis were from 0.000 to $1.200 ;-1.000$ to $0.500 ;-0.200$ to $0.120 ;-0.050$ to 0.040 and -0.010 to 0.010 for zero, first, second, third and fourth orders derivative spectra, respectively.

\section{Selectivity}

An amount of placebo cream equivalent to $20.0 \mathrm{mg}$ of HQ was weighed and transferred to a $100 \mathrm{~mL}$ graduated becker. Approximately $50 \mathrm{~mL}$ of $\mathrm{H}_{2} \mathrm{SO}_{4}(0.05 \mathrm{M})$ was added and was shaken during $10 \mathrm{~min}$ in a water bath at $40{ }^{\circ} \mathrm{C}$. This solution was transferred to a $100 \mathrm{~mL}$ volumetric flask and the volume was completed with the same solvent. The solution was filtered through Whatman ${ }^{\circledR}$ filter paper no.1, discarding first $5 \mathrm{~mL}$. Appropriate aliquots were diluted using sulfuric acid $(0.05 \mathrm{M})$ in $50 \mathrm{~mL}$ volumetric flask to obtain solutions with final concentration equivalent to $16.0,20.0$ and $24.0 \mu \mathrm{g} / \mathrm{mL}$ of placebo.

\section{Linearity}

To prepare calibration curve, accurately weighed $50.0 \mathrm{mg}$ of HQ was transferred to a $50 \mathrm{~mL}$ volumetric flask and dissolved in sulfuric acid $(0.05 \mathrm{M})$. The volume was completed with the same solvent. The above solution was systematically diluted in $25 \mathrm{~mL}$ volumetric flasks (in triplicate) to obtain final solutions containing 10.0, 14.0, $18.0,22.0$ and $26.0 \mu \mathrm{g} / \mathrm{mL}$ of $\mathrm{HQ}$.

\section{Precision}

Accurately weighed amount of cream equivalent to $15.0 \mathrm{mg}$ of HQ was transferred to a $100 \mathrm{~mL}$ graduated becker. Approximately $50 \mathrm{~mL}$ of $\mathrm{H}_{2} \mathrm{SO}_{4}(0.05 \mathrm{M})$ were added and were shaken during $10 \mathrm{~min}$ in a water bath at $40{ }^{\circ} \mathrm{C}$. This solution was transferred to a $100 \mathrm{~mL}$ volumetric flask and the volume was completed with the same solvent.

The resultant solution was filtered through Whatman filter paper no.1, discarding first $5 \mathrm{~mL}$. A $3 \mathrm{~mL}$ aliquot of this solution was diluted in a $25 \mathrm{~mL}$ volumetric flask using $0.05 \mathrm{M}$ sulfuric acid to obtain a solution with final concentration of $18.0 \mu \mathrm{g} / \mathrm{mL}$. Each sample was assayed ten times with each sample solution.

\section{Accuracy}

An accurately weighed amount of cream equivalent to $12.0 \mathrm{mg}$ of hydroquinone was transferred to a $100 \mathrm{~mL}$ volumetric flask, dissolved in approximately $50 \mathrm{~mL}$ of $0.05 \mathrm{M}$ sulfuric acid and was shaken during $10 \mathrm{~min}$ in a water bath at $40{ }^{\circ} \mathrm{C}$. After cooling, the volume was completed with the same solvent and aliquots of $10.0 \mathrm{~mL}$ of this solution were transferred into $100 \mathrm{~mL}$ volumetric flasks containing $1.0,5.0$ and $10.0 \mathrm{~mL}$ of a standard hydroquinone solution $(100.0 \mu \mathrm{g} / \mathrm{mL})$ and sulfuric acid $(0.05 \mathrm{M})$ was added to make up the volume to obtain final concentrations of 13.2, 18.0 and $24.0 \mu \mathrm{g} / \mathrm{mL}$ of HQ. All solutions were prepared in triplicate and analyzed. The percentage recovery was calculated using the equation proposed in Official Methods of Analysis of AOAC International (AOAC International, 1990).

\section{Procedure}

After homogenization of the solutions and calibration 
of the spectrophotometer with $0.05 \mathrm{M}$ sulfuric acid, the absorption spectra of each sample were obtained. The first, second, third and fourth orders derivative spectra were traced from above curves. The quantitative determinations of HQ were made at signal when there was no interfering absorption.

\section{RESULTS AND DISCUSSIONS}

The calibration curves were constructed by plotting amplitudes of the first, second, third and fourth derivative spectra versus the concentration of the HQ in $0.05 \mathrm{M}$ sulfuric acid. Table I shows statistically treated data of calibration curves.

Zero-crossing (Z-C) is the method that enables the measurement of the spectrum amplitude where the interference is cancelled till the signal of the HQ. Zero-peak (Z-P) is the method that measures the spectrum amplitude from the base line till the signal of HQ. These two methods were used for quantitative determination of HQ in creams. Figure 1 shows the zero, first, second, third and fourth orders derivative spectra of the calibration curves of HQ in $0.05 \mathrm{M}$ sulfuric acid. It was observed that at designated points, the possible interference from placebo is null. These are the most appropriate wavelengths for quantitative determination of HQ. However, between these points, there is a single wavelength that provides statistically most adequate result and at this point, determination can be made with least relative standard deviation.
After identifying the optimum wavelength and derivative order by statistic treatment (signal at $302.0 \mathrm{~nm}$ in the first derivative), the analytical method was validated and applied for quantitative determination of HQ in creams. The results can be observed in Table II. The low relative standard deviation (R.S.D.) values indicates precision of the method. In majority of the determinations it is below $2 \%$, indicating high degree of agreement (repeatability) between experimental values (Bruce et al., 1998; ICH Q2A; ICH Q2B; Shabir, 2003). Figure 2 shows UV derivative spectra of HQ standard solution, HQ sample solution and placebo of the cream. No interfering signals and overlaps were observed in placebo at $302.0 \mathrm{~nm}$ in the first derivative. A good accuracy of the method was verified with a mean recovery of $99.2 \%$ (Table III).

\section{CONCLUSIONS}

The proposed UV derivative spectrophotometric method proved to be an excellent option for HQ determination in creams. The interference from excipients was eliminated by selecting the most adequate wavelength. The first derivative with zero-peak method at $302.0 \mathrm{~nm}$ was successfully applied for quantitative determination of HQ. The proposed method can be used for analysis in routine quality control of cosmetic preparations with HQ as a unique active substance. The method is simple, rapid, precise and of low cost.

TABLE I - Statistics evaluation of the calibration curves of HQ in $0.05 \mathrm{M}$ sulfuric acid

\begin{tabular}{lcccccc}
\hline Derivative & $\begin{array}{c}\lambda \\
(\mathrm{nm})\end{array}$ & Method & $\begin{array}{c}\text { Regression equation (interval } \\
10.0-26.0 \mu \mathrm{g} / \mathrm{mL})\end{array}$ & $\begin{array}{c}\text { Correlation } \\
\text { coefficient }\end{array}$ & $\begin{array}{c}\text { R.S.D. (\%) } \\
\text { intercept }\end{array}$ & Test "a" \\
\hline 1 D & 225.8 & $\mathrm{Z}-\mathrm{C}$ & $y=-2.64 \times 10^{-2} x+1.03 \times 10^{-2}$ & -0.9923 & 1.6272 & 0.9171 \\
1 D & 302.0 & $\mathrm{Z}-\mathrm{P}$ & $y=-1.76 \times 10^{-2} x+1.41 \times 10^{-3}$ & -0.9993 & 1.5051 & 0.1985 \\
2 D & 242.8 & $\mathrm{Z}-\mathrm{C}$ & $y=1.04 \times 10^{-3} x-1.28 \times 10^{-3}$ & 0.9989 & 2.0334 & 2.4237 \\
2 D & 267.8 & $\mathrm{Z}-\mathrm{C}$ & $y=5.28 \times 10^{-4} x+6.50 \times 10^{-5}$ & 0.9976 & 2.7741 & 0.1643 \\
2 D & 306.4 & $\mathrm{Z}-\mathrm{P}$ & $y=1.97 \times 10^{-3} x+4.50 \times 10^{-5}$ & 0.9990 & 1.7709 & 0.048 \\
3 D & 221.8 & $\mathrm{Z}-\mathrm{C}$ & $y=-7.48 \times 10^{-4} x-6.50 \times 10^{-5}$ & -0.9992 & 1.5218 & 0.2118 \\
3 D & 232.0 & $\mathrm{Z}-\mathrm{P}$ & $y=8.15 \times 10^{-4} x+3.10 \times 10^{-4}$ & 0.9991 & 1.5984 & 0.8679 \\
3 D & 302.4 & $\mathrm{Z}-\mathrm{P}$ & $y=4.70 \times 10^{-4} x+2.60 \times 10^{-4}$ & 0.9988 & 1.9189 & 1.0417 \\
3 D & 311.2 & $\mathrm{Z}-\mathrm{P}$ & $y=-2.30 \times 10^{-4} x+4.00 \times 10^{-5}$ & -0.9990 & 1.7812 & 0.3672 \\
4 D & 217.4 & $\mathrm{Z}-\mathrm{C}$ & $y=-3.30 \times 10^{-4} x-1.40 \times 10^{-4}$ & -0.9981 & 2.4023 & 0.6426 \\
4 D & 235.4 & $\mathrm{Z}-\mathrm{C}$ & $y=-1.32 \times 10^{-4} x-2.15 \times 10^{-4}$ & -0.9841 & 6.6986 & 0.8276 \\
4 D & 305.6 & $\mathrm{Z}-\mathrm{P}$ & $y=-1.15 \times 10^{-4} x-9.00 \times 10^{-5}$ & -0.9962 & 3.3810 & 0.8262 \\
4 D & 313.4 & $\mathrm{Z}-\mathrm{P}$ & $y=3.25 \times 10^{-5} x-2.50 \times 10^{-5}$ & 0.9912 & 5.6469 & 0.521 \\
\hline
\end{tabular}

(Standard solutions $n=5$ ); R.S.D. = Relative Standard Deviation; Z-C = Zero-Crossing; Z-P = Zero-Peak 


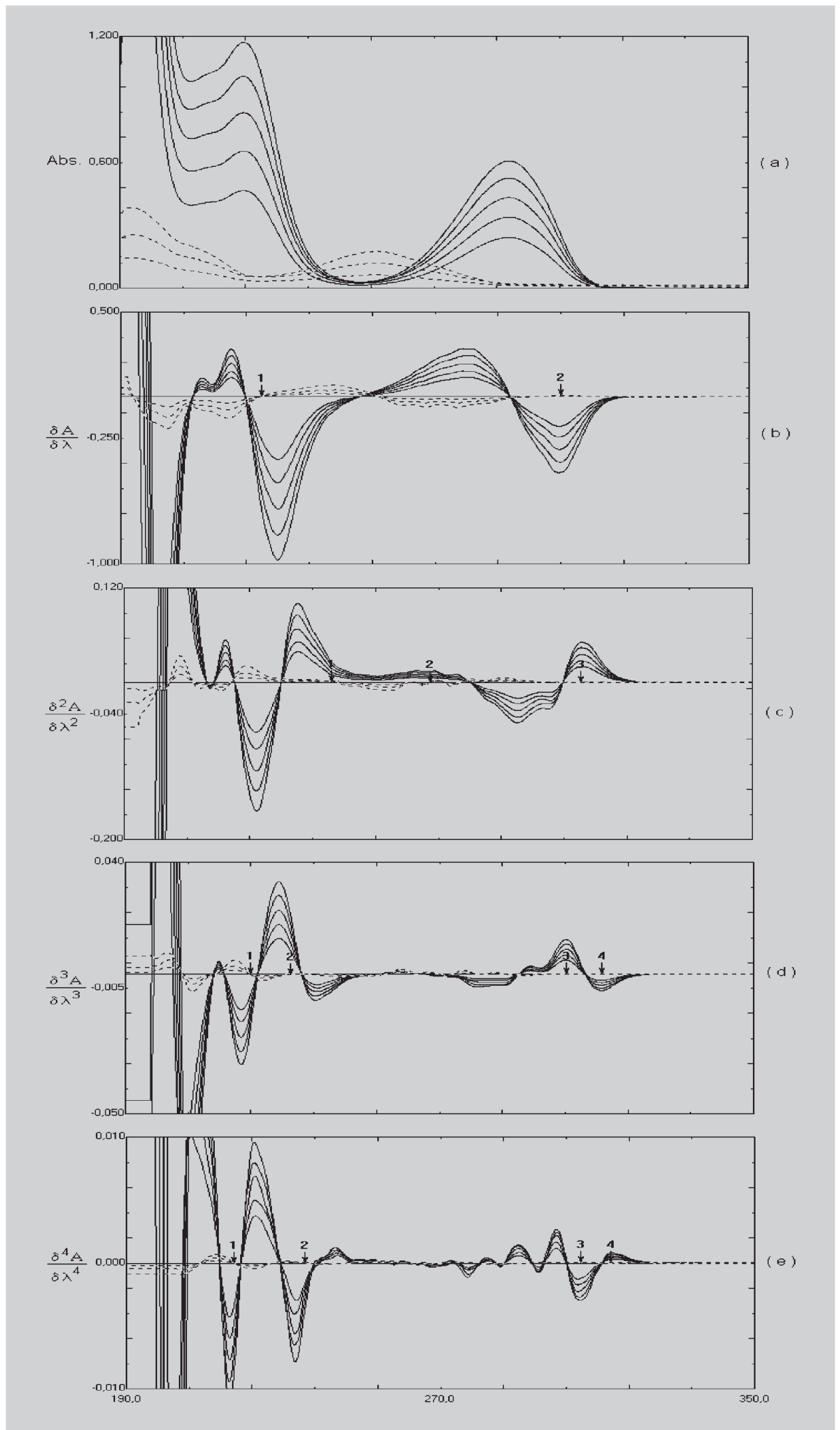

FIGURE 1 - Absorption spectra of zero (a), first (b), second (c), third (d) and fourth (e) derivative of HQ solutions (- $)$ and placebos (-----) in $0.05 \mathrm{M}$ sulfuric acid. Concentrations of 10.0, 14.0, 18.0, 22.0 and 26.0 $\mu \mathrm{g} / \mathrm{mL}$ of HQ and $16.0,20.0$ and $24.0 \mu \mathrm{g} / \mathrm{mL}$ of placebo. 


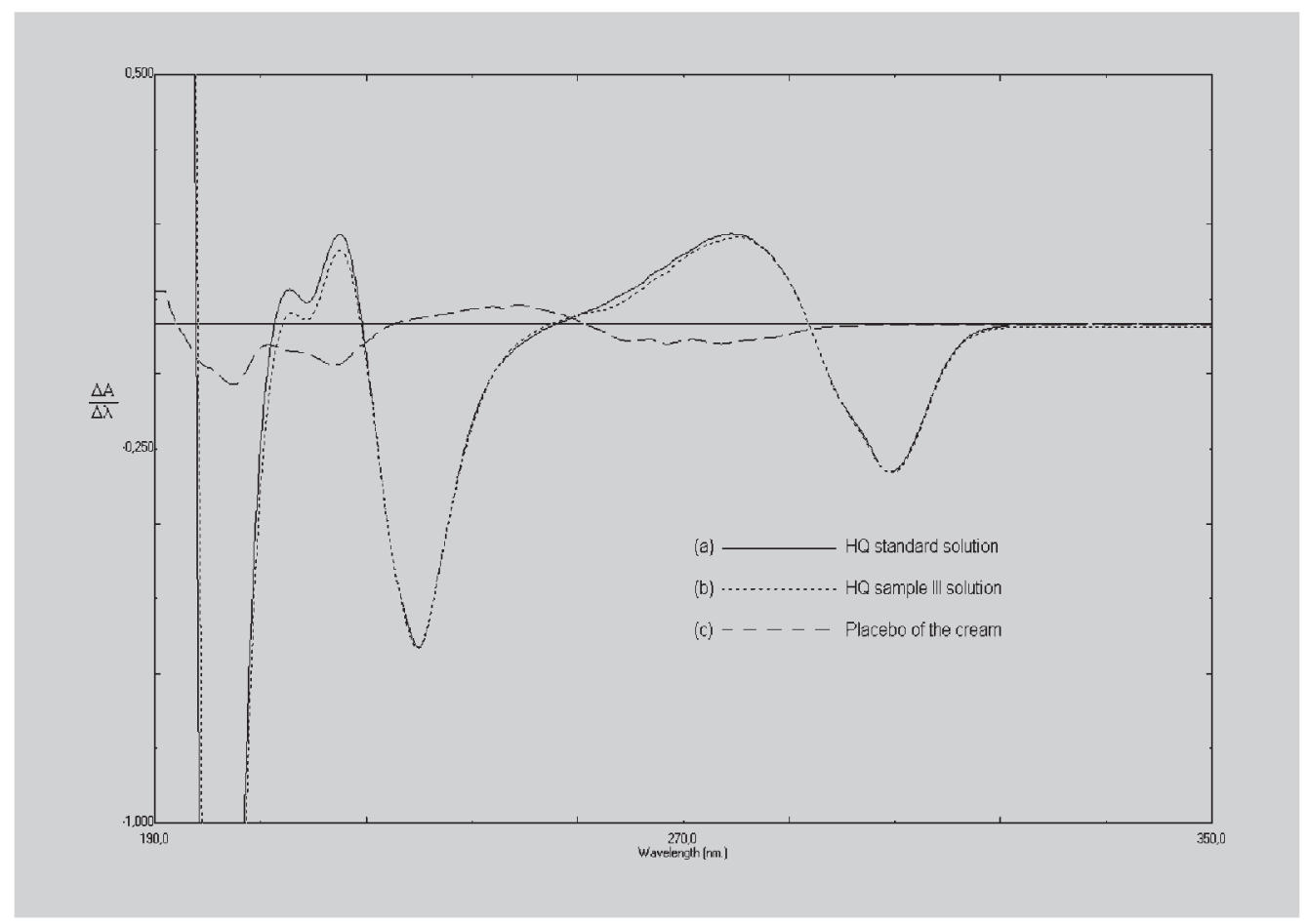

FIGURE 2 - UV derivative spectra of (a) HQ standard solution, (b) HQ sample III solution and (c) placebo of the cream in $0.05 \mathrm{M}$ sulfuric acid. Concentration $18.0 \mu \mathrm{g}$ of $\mathrm{HQ} / \mathrm{mL}$.

TABLE II - Determination of the HQ content in cream utilizing the first, second, third and fourth derivative orders in $0.05 \mathrm{M}$ sulfuric acid

\begin{tabular}{|c|c|c|c|c|c|}
\hline Sample & $\begin{array}{c}\text { Declared amount } \\
\text { HQ }(\mathrm{g} / 100 \mathrm{~g})\end{array}$ & $\begin{array}{c}\text { Found amount* } \\
\text { HQ }(\mathrm{g} / 100 \mathrm{~g})\end{array}$ & $\begin{array}{l}\text { Amount } \\
(\%)\end{array}$ & $\begin{array}{c}\text { R. S. D. } \\
(\%)\end{array}$ & $\begin{array}{c}\text { C. I. } \\
\mathrm{P}=95 \%\end{array}$ \\
\hline \multicolumn{6}{|c|}{ First derivative $302.0 \mathrm{~nm}$} \\
\hline I & 2 & 1.870 & 93.5 & 0.968 & 0.12 \\
\hline II & 4 & 3.916 & 97.9 & 0.854 & 0.11 \\
\hline III & 4 & 4.057 & 101.4 & 0.812 & 0.11 \\
\hline \multicolumn{6}{|c|}{ Second derivative $306.4 \mathrm{~nm}$} \\
\hline I & 2 & 1.870 & 93.5 & 1.174 & 0.14 \\
\hline II & 4 & 3.876 & 96.9 & 1.463 & 0.18 \\
\hline III & 4 & 4.012 & 100.3 & 1.121 & 0.14 \\
\hline \multicolumn{6}{|c|}{ Third derivative $221.8 \mathrm{~nm}$} \\
\hline I & 2 & 1.873 & 93.6 & 2.363 & 0.28 \\
\hline II & 4 & 3.873 & 96.8 & 1.331 & 0.16 \\
\hline III & 4 & 3.988 & 99.7 & 1.432 & 0.18 \\
\hline \multicolumn{6}{|c|}{ Fourth derivative $217.4 \mathrm{~nm}$} \\
\hline I & 2 & 1.717 & 85.8 & 1.994 & 0.22 \\
\hline II & 4 & 3.664 & 91.6 & 1.292 & 0.15 \\
\hline III & 4 & 3.678 & 91.9 & 0.869 & 0.12 \\
\hline
\end{tabular}

$* \mathrm{n}=10 ;$ R.S.D. $=$ Relative Standard Deviation; C.I. $=$ Confidence Interval 
TABLE III - Recovery of a standard HQ content added to cream and determined by first derivative at $302.0 \mathrm{~nm}$ in $0.05 \mathrm{M}$ sulfuric acid

\begin{tabular}{cccc}
\hline Sample & $\begin{array}{c}\text { Concentration } \\
\text { added }(\mu \mathrm{g} / \mathrm{mL})\end{array}$ & $\begin{array}{c}\text { Concentration } \\
\text { found }(\mu \mathrm{g} / \mathrm{mL})\end{array}$ & $\begin{array}{c}\text { Recovery } \\
(\%)^{\mathrm{a}}\end{array}$ \\
\hline I & 1.20 & 1.18 & $98.30 \pm 0.80$ \\
II & 6.00 & 5.90 & $98.30 \pm 0.81$ \\
III & 12.00 & 12.00 & $100.00 \pm 0.80$ \\
& & & $100.00 \pm 0.70$ \\
I & 1.20 & 1.20 & $99.20 \pm 0.78$ \\
II & 6.00 & 5.95 & $98.30 \pm 0.78$ \\
III & 12.00 & 11.80 & $100.00 \pm 0.70$ \\
& & & $98.80 \pm 0.67$ \\
I & 1.20 & 1.20 & $98.40 \pm 0.69$ \\
II & 6.00 & 5.93 & \\
III & 12.00 & 11.81 & \\
\hline
\end{tabular}

$\mathrm{a}=$ mean of three determination

\section{RESUMO}

\section{Determinação do comprimento de onda ótimo e da ordem da derivada em espectrofotometria para quantificação de hidroquinona em cremes}

A espectrofotometria derivada no UV foi usada para a determinação quantitativa de hidroquinona em cremes. $O$ objetivo desta pesquisa foi investigar o melhor comprimento de onda e a ordem da derivada, bem como validar o método proposto. Os resultados das curvas analíticas foram analisados estatisticamente pelo método dos mínimos quadrados no intervalo de 10,0 a 26,0 $\mu \mathrm{g} / \mathrm{mL}$, na primei$r a$, segunda, terceira e quarta ordens da derivada. As determinações quantitativas foram realizadas utilizando os métodos "zero-crossing (Z-C)" e zero-pico (Z-P). O método proposto é simples, de baixo custo e fornece resultados confiáveis podendo ser usado no controle de qualidade de cremes contendo hidroquinona como substância ativa.

UNITERMOS: Hidroquinona. Espectrofotometria derivada no UV. Controle de qualidade

\section{ACKNOWLEDGMENTS}

We acknowledge CNPq (Conselho Nacional de Desenvolvimento Científico e Tecnológico - Brasil) for the financial support.

\section{REFERENCES}

AOAC INTERNATIONAL. Official Methods of Analysis, 15 Ed. Arlington: AOAC INTERNATIONAL, 1990. p.21.

BLEEHEN, S.S. Skin bleaching preparations. J. Soc. Cosmet. Chem., New York, v.28, p.407-412, 1977.

BORREMANS, M.; DE BEER, J.; GOEYENS, L. Experimental and statistical validation of HPLC analysis of hydroquinone and its 4-methoxyphenol, 4ethoxyphenol and 4-benzyloxyphenol ethers in cosmetic products. Chromatographia, Wiesbaden, v.50, n.5/6, p.346-352, 1999.

BRUCE, P.; MINKKINEN, P.; RIEKKOLA, M.-L. Practical method validation: validation sufficient for an analysis method. Mikrochim. Acta, Wien, v.128, n.1/2, p.93-106, 1998.

CECIL, R.L.; WYNGAARDEN, J.B.; SMITH Jr., L.H.; BENNETT, J.C., eds. Cecil tratado de medicina interna. 19.ed. Rio de Janeiro: Guanabara Koogan, 1993. v.2, p.2370-2371.

CONNORS, K.A.;AMIDON, G.L.; STELLA, V.J. Chemical stability of pharmaceuticals: a handbook for pharmacists. 2.ed. New York: John Wiley, 1986. p.82-93. 
CRUZ, V.I.; FATIBELLO-FILHO, O. Biosensor based on paraffin/graphite modified with sweet potato tissue for the determination of hydroquinone in cosmetic cream in organic phase. Talanta, Amsterdam, v.52, n.4, p.681-689, 2000.

DESIDERIO, C.; OSSICINI, L.; FANALI, S. Analysis of hydroquinone and some of its ethers by using capillary electrochromatography. J. Chromatogr., A, Amsterdam, v.887, n.2, p.489-496, 2000.

FIRTH, J.; RIX, I. Determination of hydroquinone in skintoning creams using high-performance liquid chromatography. Analyst, Letchworth, v.111, n.2, p.129132, 1986.

GAGLIARDI, L.; AMATO, A.; CAVAZZUTTI, G.; CHIMENTI, F.; BOLASCO, A.; TONELLI, D. Identification and quantification of hydroquinone and some of its ethers in cosmetic products by reversed-phase high-performance liquid chromatography. $J$. Chromatogr., Amsterdam, v.404, n.1, p.267-272, 1987.

HACKMANN, E.R.M.; BENETON, S.A.; SANTORO, M.I.R.M. Espectrofotometria derivada na análise de fármacos em medicamentos. Rev. Port. Farm., Lisboa. v.41, n.1, p.7-13, 1991.

HARDMAN, J.G.; LIMBARD, L.E.; MOLINOFF, P.B.; RUDDON, R.W.; GILMAN, A.G., eds. Goodman \& Gilman's The pharmacological basis of therapeutics. 9.ed., New York: McGraw-Hill, 1996. p.1216.

HOPKALA, H.; KOWALCZUK, D. Application of derivative UV spectrophotometry for the determinantion of enoxacin and nalidixic acid in tablets. Pharmazie, Eschborn, v.55, n.6, p.432-435, 2000.

INTERNATIONAL CONFERENCE ON HARMONIZATION (ICH); validation of analytical procedures: Definitions and terminology, Q2A(CPMP/ ICH/381/95), 1995. Disponível em: http://www.ich.org. Acesso em: 24 jul. 2006.

INTERNATIONAL CONFERENCE ON HARMONIZATION (ICH); validation of analytical procedures: Methodology, Q2B (CPMP/ICH/281/95), 1995. Disponível em: http://www.ich.org. Acesso em: 24 jul. 2006.
KARPIÑSKA, J. Derivative spectrophotometry-recent applications and directions of developments. Talanta. Amsterdam, v.64, n.4, p.801-822, 2004.

KATSAMBAS, A.; ANTONIOU, CH. Melasma: classification and treatment. J. Eur. Acad. Dermatol. Venereol., Amsterdam, v.4, n.3, p.217-223, 1995.

GARCIA, P.L.; SANTORO, M.I.R.M; KEDORHACKMANN, E.R.M.; SINGH, A.K. Development and validation of a HPLC and a UV derivative spectrophotometric methods for determination of hydroquinone in gel and cream preparations $J$. Pharm. Biomed. Anal., Oxford, v.39, n.3/4, p.764-768, 2005.

MOHAMED, A.; MOHAMED, M. Topical hydroquinone in the treatment of some hyperpigmentary disorders. Int. J. Dermatol., Oxford, v.37, n.6, p.449-450, 1998.

PALUMBO, A.; D’ISCHIA, M.; MISURACA, G.; PROTA, G. Mechanism of inhibition of melanogenesis by hydroquinone. Biochim. Biophys. Acta, Amsterdam, v.1073, n.1, p.85-90, 1991.

RUEDA, M.E.; SARABIA, L.A.; HERRERO, A.; ORTIZ, M.C. Optimisation of a flow injection system with electrochemical detection using the desirability function application to the determination of hydroquinone in cosmetic. Anal. Chim. Acta, Amsterdam, v.479, n.2, p.173-184, 2003.

SAKODINSKAYA, I.K.; DESIDERIO, C.; NARDI, A.; FANALI, S. Micellar electrokinetic chromatographic study of hydroquinone and some of its ethers. determination of hydroquinone in skin-toning cream. $J$. Chromatogr., Amsterdam, v.596, n.1, p.95-100, 1992.

SHABIR, G.A. Validation of high-performance liquid chromatography methods for pharmaceutical analysis. understanding the differences and similarities between validation requeriments of the US Food and Drug Administration, the US Pharmacopeia and the International Conference on Harmonization. $J$. Chromatogr., A, Amsterdam, v.987, n.1/2, p.57-66, 2003.

SILVA, P.; RESENDE, A., coords. Farmacologia . 5.ed. Rio de Janeiro: Guanabara Koogan, 1998. p.1242.

ULLMANN'S encyclopedia of Industrial organic chemicals; starting materials and intermediates. Weinheim: WileyVCH, 1999. v.5, p.2941-2953. 
WANG, L. Simultaneous determination of hydroquinone ethers in cosmetic after preconcentration at a carbon paste electrode. Analyst, Letchworth, v.120, n.8, p.2241-2244, 1995.
ZANINI, A.; OGA, S. Farmacologia aplicada. 4.ed. São Paulo: Atheneu, 1989. p.429.

Recebido para publicação em 23 de agosto de 2006. Aceito para publicação em 14 de junho de 2007. 